\title{
WSPÓŁPRACA TRANSGRANICZNA UKRAINY I POLSKI W STRUKTURZE STOSUNKÓW MIĘDZYNARODOWYCH NA PRZYKŁADZIE WYBRANYCH EUROREGIONÓW (ZARYS I PROBLEMATYKA)
}

\author{
Abstract \\ CROSS-BORDER COOPERATION BETWEEN UKRAINE AND POLAND \\ IN THE STRUCTURE OF INTERNATIONAL RELATIONS WITH SELECTED \\ EUROREGIONS AS CASE STUDIES (OUTLINE AND ISSUES)
}

Cross-border co-operation is a vital element of the cooperation between Ukraine and Poland in the institutional sphere, where priority directions of growth are determined mostly by social, cultural, and educational co-operation and the development of infrastructure. The objective of this paper is to present the cross-border cooperation between Poland and Ukraine in the structure of international relations. I discuss the cooperation of Euroregions located on the Polish-Ukrainian border (including Bug, Superior Prut and Lower Danube, Carpathian, Dnepr, and Slobozhanschina) on the cross-border and regional levels. The paper is based on the qualitative methods of field research (including in six Ukrainian oblasts: Volyn, Zakarpattia, Ivano-Frankivsk, Lviv, Odesa, Chernivtsi, and Chernihiv.) Furthermore, I have analysed secondary sources and the principles of cross-border cooperation between Poland and Ukraine available on the Internet. The research has demonstrated a dynamic and progressive development of cross-border cooperation as a bilateral dialogue at local and regional levels, which leads to intensified interinstitutional contacts and cross-border movement. Additionally, the research has revealed key problems in this domain that could be overcome following a thorough diagnosis based on scientific research.

SŁOWA KLUCZE: współpraca transgraniczna, euroregiony, polsko-ukraińska współpraca, współpraca społeczna, kulturalno-oświatowa współpraca

KEY WORDS: cross-border cooperation, euroregions, polish-ukrainian cooperation, social cooperation, cultural and educational cooperation 
Współczesne stosunki międzynarodowe charakteryzują się dość intensywnymi procesami integracyjnymi, spośród których ważną rolę odgrywa współpraca transgraniczna. Określenie „współpraca transgraniczna” rozumiem tu w znaczeniu zaproponowanym przez Zdzisława Brodeckiego, które oznacza wspólne przedsięwzięcia jednostek samorządowych różnych państw sąsiadujących z sobą poprzez wspólną granicę. Cechami wyróżniającymi tę formę współpracy zewnętrznej są: lokalny lub regionalny poziom współpracy, sąsiedzkość kontaktów (przyległość obszarów). Współpraca międzyterytorialna $\mathrm{z}$ kolei to: partnerska współpraca jednostek bezpośrednio z sobą niegraniczących (może dotyczyć także jednostek z państw spoza obszaru Europy), uczestnictwo w międzynarodowych organizacjach, zrzeszeniach oraz instytucjach jednostek lokalnych i regionalnych ${ }^{1}$.

Jak zauważyli po zakończeniu II wojny światowej politycy, a wraz z nimi badacze stosunków międzynarodowych i współpracy międzypaństwowej, granice są „,bliznami historii”, dzielą, tworzą konflikty, rozdzielają na poziomie etnicznym i kulturowym, ekonomicznym i rodzinnym, tworząc $w$ ten sposób niepotrzebne bariery ${ }^{2}$. To właśnie pod wpływem takich rozważań współpraca transgraniczna stała się bodźcem społeczno-ekonomicznego rozwoju regionów oraz sposobem na zmniejszanie terytorialnych dysproporcji, które w nich występują. Tworzenie od roku 1981 euroregionów stało się jedną z najbardziej efektywnych form takiej współpracy na poziomie ekonomicznym, gospodarczym, ekologicznym, przyrodniczym i kulturowym ${ }^{3}$.

Dzięki korzystnemu położeniu geopolitycznemu Ukraina ma wielkie możliwości rozwoju, ponieważ aż 19 z 25 regionów państwa leży przy granicy i graniczy w tym z Polską, Białorusią, Rosją, Mołdowią, Rumunią, Węgrami i Słowacją. Współpraca transgraniczna jest ważnym elementem ukraińsko-polskiej współpracy w sferze międzyinstytucjonalnej, w której priorytetowe kierunki rozwoju to przede wszystkim akcent na współpracę społeczną, a w tym zakresie - regulację procesów migracyjnych oraz wykorzystanie siły roboczej w celu zapobiegania postępującemu bezrobociu na pograniczach państwowych. Promuje pomoc w zatrudnianiu ludności; prowadzenie ustalonej polityki w sferze stosunków pracy, warunków ochrony pracy; harmonizację środków ubezpieczenia oraz pomocy medycznej i innych. Współpraca na pograniczach polsko-ukraińskich ma także na celu wzmocnienie pozycji kulturalno-oświatowej, a mianowicie wymianę specjalistów, koordynację programów edukacyjnych, pomoc $\mathrm{w}$ organizacji i przygotowaniach zawodowych oraz przekwalifikowaniu kadr. W jej ramach dąży się do nawiązania współpracy ośrodków edukacji, nauki i kultury oraz przeprowadzenia wspólnych wydarzeń o charakterze humanistycznym. Umowy euroregionów pozwalają też na rozwój przygranicznej infrastruktury - modernizację i rozwój istniejącej sieci transportowej w celu zwiększenia jej przepustowości; stworzenie, rozwój i zapewnienie warunków do bezproblemowego

1 Z. Brodecki, Regiony, Warszawa 2005, s. 209.

2 Europejska Karta Regionów Granicznych i Transgranicznych (do 1995 r. - Europejska Karta Regionów Przygranicznych), http://docplayer.pl/7365320-Europejska-karta-regionow-granicznych-i-transgranicznych-nowelizacja.html [odczyt: 23.06.2016].

3 Tamże. 
przekraczania granicy, działalności sieci transportowych oraz komunikacji; koordynacja planów budowy infrastruktury drogowej, a także rozbudowa obiektów infrastruktury produkcyjnej i socjalnej.

Jeśli chodzi o pozytywny wpływ, to realizacja Programu sprzyja rozwiązaniu problemów międzyregionalnych rozwoju gospodarczego, podwyższeniu poziomu integracji gospodarczej i społecznej regionów oraz podniesieniu jakości życia obywateli. W ramach programu realizowany jest projekt „Strategia współpracy transgranicznej Lublin-Luck-Lwów-Iwano-Frankowsk", który rozpoczęto w celu opracowania strategii współpracy transgranicznej od roku 2007 do 2013, oraz „Protokół zamiarów wspólnej strategii transgranicznej współpracy międzyregionalnej wzdłuż granicy ukraińsko-polskiej między ukraińskimi obwodami wołyńskim, zakarpackim i lwowskim oraz polskimi województwami: lubelskim i podkarpackim”, podpisany 7 października 2005 roku'.

W celu rozszerzenia kontaktów i współpracy na poziomie transgranicznym i regionalnym z sąsiadującymi krajami wzdłuż ukraińskiej granicy państwowej od lat dziewięćdziesiątych XX wieku powstawały tzw. euroregiony na granicach Polski i Ukrainy. Obecnie jest ich sześć. W przypadku Polski i Ukrainy tego typu współpraca została zinstytucjonalizowana początkowo w postaci: Euroregionu Karpackiego i Euroregionu Bug 5 .

Chronologicznie struktury te w Polsce powstały stosunkowo wcześnie. Euroregion Karpacki utworzono jako pierwszy w kolejności (rok 1993), natomiast Bug powstał jako szósty (1995 rok) ${ }^{6}$. Obejmują one swoim zasięgiem całą granicę polsko-ukraińską i są największe wśród wszystkich istniejących euroregionów w Polsce. Euroregion Bug - powstały 29 września 1995 roku - obejmuje pogranicze Polski, Białorusi i Ukrainy o powierzchni 80,9 tys. $\mathrm{km}^{2}$, Euroregion Karpacki - założony 14 lutego 1992 roku - obejmuje pograniczne obszary Polski i Ukrainy, a ponadto także Słowacji, Węgier i Rumunii o łącznej powierzchni 61,2 tys. $\mathrm{km}^{2}$. Do form organizacyjnej współpracy jednostek administracyjno-terytorialnych państw europejskich włączono sześć obwodów Ukrainy - wołyński, zakarpacki, iwano-frankowski, lwowski, czerniowiecki i czernichowski.

Dużym impulsem aktywizacji współpracy transgranicznej na granicy zachodniej Ukrainy było rozszerzenie formatu współpracy poprzez wprowadzenie przez Unię Europejską nowych Programów Sąsiedztwa. Po przystąpieniu Polski do Unii Europejskiej w 2004 roku, rozpoczęto realizację programu sąsiedztwa „Polska - Białoruś - Ukraina”, którego celem jest polepszenie sytuacji społeczno-ekonomicznej w przygranicznych jednostkach administracyjno-terytorialnych państw - uczestników tego programu, a także nasilenie transgranicznego partnerstwa instytucjonalnego.

${ }^{4}$ Europejska Karta Regionów Granicznych i Transgranicznych (do 1995 r. - Europejska Karta Regionów Przygranicznych), http://docplayer.pl/7365320-Europejska-karta-regionow-granicznych-i-transgranicznych-nowelizacja.html [odczyt: 23.06.2016].

${ }_{5}$ B. Surmacz, Wspótczesne stosunki polsko-ukraińskie. Politologiczna analiza traktatu o dobrym sąsiedztwie, Lublin 2002, s. 191-206.

${ }^{6}$ J. Andreasik, B. Kawałko, E. Kawecka-Wyrzykowska, Perspektywy przygranicznej wspótpracy polsko-ukraińskiej w świetle czlonkostwa Polski w Unii Europejskiej, Zamość 2003. 
Program posiada znaczny potencjał do rozszerzenia współpracy ukraińsko-polskiej oraz wzmocnienia więzi transgranicznych. Współpraca obwodów - uczestników prowadzona jest w ramach organizacji międzynarodowych. Należą do nich: Stowarzyszenie Europejskich Regionów Przygranicznych, Związek Regionów Europejskich, Kongres Władz Lokalnych i Regionalnych Rady Europy i inne ${ }^{7}$. Działania organizacyjne, zapoczątkowujące programy sąsiedztwa, rozpoczęto w roku 2004. Przewidywały one utworzenie wspólnych komitetów, wspólnych sekretariatów technicznych dla każdego programu. Odpowiedzialnymi za przygotowanie wspólnego dokumentu programowego przez Eurokomisję oraz Rząd Ukrainy były Ministerstwo Gospodarki na poziomie państwowym oraz administracje obwodowe celowych terytoriów na poziomie regionalnym. W wyniku wspólnych działań opracowano dokumenty programowe oraz mechanizmy zarządzania i realizacji każdego z programów. Przykładem pierwszych udanych projektów Programu Sąsiedztwa (rok 2000) są: opracowanie i wprowadzenie transgranicznego socjalno-medycznego programu rehabilitacyjnego dla dzieci - przedstawicieli mniejszości narodowych i społecznie bezbronnych warstw społecznych (Mukaczewski obwodowy szpital dziecięcy); projekt słowacko-ukraińskiej współpracy transgranicznej w sferze turystyki (Organizacja Non-profit „Panonia” w roku 2002); utworzenie Centrum Ukraińsko-Polskich Inicjatyw w mieście Użhorod (Fundacja Rozwoju Współpracy Transgranicznej (rok 2005) oraz Międzynarodowe Stowarzyszenie Instytucji Rozwoju Regionalnego „MAIPP ( 2006)” .

Polska to jeden z krajów, które graniczą z Zakarpaciem, dlatego też rozwój kontaktów ze stroną polską jest jednym z głównych kierunków współpracy transgranicznej na poziomie obwodu. Na tym poziomie znajdują się więzi handlowe, działalność inwestycyjna pomiędzy Polską i Zakarpaciem, ale przy tym, na odcinku $32 \mathrm{~km}$ wspólnej granicy nie ma żadnego punktu przejścia, co hamuje rozwój współpracy transgranicznej pomiędzy Zakarpaciem i województwem podkarpackim Polski. W celu polepszenia sytuacji zakarpacka obwodowa administracja państwowa zainicjowała utworzenie pieszego punktu przejścia granicznego na granicy ukraińsko-polskiej w rejonie Łubnia-Wołosatego. Kwestia ta została uzgodniona ze stroną polską i obecnie na poziomie MSZ Ukrainy prowadzone są konsultacje dotyczące podpisania międzyrządowego porozumienia o otwarciu takiego przejścia.

Zakarpacka OAP dokłada starań, aby zaspokoić kulturalne, edukacyjne i duchowe potrzeby mniejszości narodowych kraju, w tym także Polaków. W obwodzie działa Towarzystwo Kultury Polskiej oraz polska szkółka weekendowa. Zakarpacka OAP we współpracy z organizacjami społecznymi kraju bierze udział w opracowaniu Europejskiego instrumentu sqsiedztwa i partnerstwa Polska-Białoruś-Ukraina na lata 2007-2013. Pozytywnie wpłynęło na rozwój współpracy transgranicznej podpisanie porozumienia o małym ruchu granicznym pomiędzy Ukrainą a Polską. Ale w wielu przypadkach regionalne i lokalne organy władzy nie są gotowe do podjęcia

${ }^{7}$ M. Leseczko, Globalizacja a rozwój Ukrainy [w:] M. Bałtowski, H. Ponikowski (red.), Problemy rozwoju i zarza-dzania w gospodarce globalnej, Lublin 2005, s. 45-76.

8 В. Чорногор, Центр украӥнсько-польських ініціатив” допомагатиме розвитку прикордонного співробітництва „Новини Закарпаття” 2007, s. 4. 
współpracy transgranicznej jako sfery, która wymaga od nich funkcji koordynacyjnych oraz kontrolnych, przestrzegania czynnego prawodawstwa podczas jego wdrażania, ale w żadnym wypadku niestosowania ostrej kontroli i regulacji administracyjnych, w odróżnieniu od krajów Europy Środkowo-Wschodniej, szczególnie Polski, z którymi Ukraina posiada wspólną granicę i w których do wspólnych organów euroregionów delegowani są przedstawiciele sektora obywatelskiego oraz biznesowego, przygraniczne regiony naszego kraju, które są ich członkami, w tych wspólnych organach reprezentowane są zwykle przez urzędników państwowych, co także nie sprzyja szybkiemu i efektywnemu przyłączaniu sektora obywatelskiego do współpracy transgranicznej.

Jak wiadomo, sąsiednie tereny Polski mają jeszcze z końca lat osiemdziesiątych i początku lat dziewięćdziesiątych zeszłego wieku tradycje współpracy przygranicznej, szczególnie uczestnictwo od 1993 roku w Stowarzyszeniu „Euroregion Karpacki”. Przez lata niepodległości Ukrainy na poziomie regionów poczyniono znaczne kroki w celu efektywnego wykorzystania tych możliwości, wprowadzenia nowych form, które odpowiadałyby realiom obecnych czasów. Szczególnie odnowiono tradycyjne święta dla mieszkańców terenów przygranicznych. Tradycyjne stały się obchody Dnia dobrego sąsiedztwa na ukraińsko-polskim odcinku granicy. W dniu dobrego sąsiedztwa odbywają się spotkania, w których bierze udział średnio 450500 osób z terytoriów przygranicznych. Uroczystości transgraniczne poświęcone są głównie tematyce ukraińsko-polskiego pogranicza: odbywają się spotkania studentów ukraińskich i polskich, przeprowadzane są międzynarodowe spotkania młodzieżowe (,Jedna Europa - różne spojrzenia” w ramach programu „Młodzież” Unii Europejskiej w 2006 roku), wykonywane są prace restauracyjne cmentarzy (cmentarz w mieście Korczmin - rok 2006) i inne. Międzyregionalne wydarzenia na granicy, takie jak dni dobrego sąsiedztwa, obejmują różne warstwy ludności i wzmacniają istniejącą współpracę, a także gwarantują powstanie nowego partnerstwa między organami władzy a samorządem, organizacjami społecznymi i strukturami biznesowymi regionów przygranicznych ${ }^{9}$.

Obecnie współpraca transgraniczna staje się znaczącym instrumentem stałego rozwoju obszarów przygranicznych poprzez zmianę międzyregionalnych i transgranicznych więzi, otrzymywanie dodatkowych środków w formie międzynarodowej pomocy technicznej i inwestycji krajów sąsiedzkich, a także jest najważniejszym czynnikiem tworzenia pozytywnego wizerunku inwestycyjnego regionu.

W ostatnich latach harmonijnie rozwijał się Euroregion Bug, który został utworzony 29 września 1995 roku. W jego skład weszły: obwód wołyński i dawne województwa chełmskie, lubelskie, tarnobrzeskie i zamojskie Rzeczpospolitej Polskiej. W maju 1998 roku dołączono do niego polskie dawne województwo bialsko-podlaskie i obwód brzeski Republiki Białoruś.

Utworzenie Euroregionu Bug zainicjowane zostało przez lokalne organy władzy, które wyszły z założenia, że tylko wspólne działania, ochrona i wzmocnienie

9 B. Surmacz, Wspótczesne stosunki polsko-ukraińskie. Politologiczna analiza traktatu o dobrym sasiedztwie, Lublin 2002, s. 91-106. 
przyjaznych stosunków dobrosąsiedzkich mogą zapewnić zrównoważony rozwój społeczny i ekonomiczny terytoriów, a także polepszenie jakości życia narodu. W regionie odbywa się wiele wydarzeń, których celem jest pogłębienie współpracy transgranicznej i międzyregionalnej pomiędzy lokalnymi władzami samorządowymi i władzy wykonawczej obwodów wołyńskiego i brzeskiego oraz województwa lubelskiego, a także między kołami biznesowymi, specjalistami w dziedzinie ochrony środowiska, ochrony pracy, działalności związków zawodowych i kultury.

Najistotniejszym programem unijnym realizowanym na płaszczyźnie kulturalnej jest program ramowy Kultura 2000. Ten projekt stanowi przykład programu pomocowego, realizowanego w ramach Wspólnot Europejskich. Wspiera on też programy rozwijające kulturę europejską, różnorodność kulturową w ramach kontynentu europejskiego, wzajemne poznawanie kultury i historii narodów europejskich oraz ochronę dziedzictwa kultury europejskiej ${ }^{10}$. Jeszcze jednym pozytywnym przykładem jest rozwój sfery turystycznej oraz współpracy transgranicznej, które realizowane są na postawie dokumentów programowych, a przede wszystkim Państwowego programu rozwoju turystyki na lata 2002-2010 oraz Państwowego programu rozwoju współpracy transgranicznej na lata 2007-2010. Programy te zawierają sposoby zwiększenia konkurencyjności w branży turystycznej na rynku krajowym i zagranicznym ${ }^{11}$. Przesłankami rozwoju ukraińsko-polskiej współpracy transgranicznej w sferze turystyki są: istnienie znacznej ilości zasobów turystyczno-rekreacyjnych oraz pamiątek kulturalno-historycznych związanych ze wspólną przeszłością historyczną; możliwość włączenia środków z funduszy strukturalnych Unii Europejskiej do rozwoju współpracy w ramach Programu Dobrego Sąsiedztwa „Polska-Białoruś-Ukraina” w celu realizacji wspólnych projektów transgranicznych w różnych sferach, szczególnie w turystyce i rekreacji (międzynarodowe trasy turystyczne „Śladami dzielnego wojaka Szwejka”, „Zielone koło” i inne); wspólna organizacja przez Ukrainę i Polskę Mistrzostw Europy w piłce nożnej w 2012 roku, drugie miejsce Polski pod względem ruchu turystycznego wjazdowego i wyjazdowego (zgodnie z oficjalnymi danymi Państwowej Służby Turystyki i Kurortów ).

Funkcjonowanie Programów Sąsiedztwa na Ukrainie na poziomie regionalnym stwarza zarówno nowe możliwości, jak i problemy. Ten program pokazał nie tylko znaczenie synchronizacji działań regionów przygranicznych, ale również brak kompetencji organów władzy oraz samorządu w regionach przygranicznych. Także różne okresy wskazują na rozmaite problemy związane ze współpracą Ukrainy i Polski, które są sąsiadami, ale funkcjonują na różnych płaszczyznach prawnych. Oprócz tego, razem z nowymi możliwościami pojawiają się nowe problemy: istniejące różnice w poziomach życia w krajach, które leżą po różnych stronach granicy, ujawniają się ze zdwojoną siłą - poprzez szybkie tempo rozwoju w krajach będących członkami

${ }_{10}$ Z. Brodecki, A. Mikołajczyk, A. Skóra, T. Sowiński, W. Wiewiórowski, K. Zeidler, Regiony w wybranych państwach czlonkowskich Unii Europejskiej, Warszawa 2005.

11 Державна Програма розвитку транскордонного співробітнищтва на 2007-2010 p.p.: за станом на 27 груд. 2006 p./Постанова Кабінету Міністрів України / Урядовий портал, //http:// www.kmu.gov.ua/control/uk/cardnpd?docid=60690971 [odczyt: 04.09.2016]. 
Unii Europejskiej i wolniejsze w sąsiednich krajach, spoza niej. Warto wspomnieć o konfliktach narodowych, etnicznych i religijnych powstałych pod wpływem różnych ideologii, także państwowych (inne mitologie), oraz Kościołów itd., które często nie dostrzegają specyfiki terenów przygranicznych i powstającej tu unikatowej kultury (łączącej, a nie dzielącej, podwójnej, a nawet potrójnej tożsamości ludzi tu żyjących), a chcą rozdzielać i przyciągać mieszkańców pograniczy do określonego jednego centrum państwowego. Tymczasem tożsamość osób zamieszkujących na pograniczach jest złożona i wielokulturowa, trudno przyporządkować ją do jednej narodowości czy etnosu. Wszystkie wymienione przeszkody stanowią zagrożenie nie tylko dla powstania i realizacji w odpowiednim czasie wspólnych projektów, ale również negatywnie wpływają na dalszy rozwój współpracy transgranicznej.

W celu wykorzystania nowych możliwości sąsiedztwa z RP - członkiem UE, a także w celu neutralizacji możliwie negatywnego wpływu istniejących różnic w poziomie życia, powstaje konieczność rozwiązywania problemów w regionach przygranicznych, w takich kierunkach, jak rozwój infrastruktury przygranicznej i transportowej, obrona wspólnych granic, bezpieczeństwo ekologiczne, uproszczenie procedur przekraczania granicy, ochrona przed przestępczością oraz walka z nią; ochrona środowiska naturalnego raz ochrona zdrowia, rozwój więzi kulturalnych po obu stronach granicy. W toku stałych zmian politycznych zarówno na ogólnopaństwowym, jak i regionalnym poziomie, aktywnymi graczami w sferze rozwiązywania problemów społeczno-ekonomicznych stają się organizacje społeczne, które stale zwiększają potencjał i doświadczenie pracy w sferze zarządzania projektami oraz działalności zagranicznej, tworzą rozbudowane i skuteczne sieci partnerskie, aktywnie współpracują z organami władzy w realizacji programów branżowych ${ }^{12}$.

Niestety, ścisłej wspólpracy nie sprzyja istnienie tylko kilku przejść granicznych na ukraińsko-polskiej granicy, których moc przepustowa nie odpowiada tempu rozwoju stosunków ekonomicznych oraz humanitarnych Ukrainy i Polski. Ich przeciążenie, nieodpowiednie rozmiary, a także przepustowość z polskiej i ukraińskiej strony, nieefektywność wykorzystania istniejących możliwości, nieskoordynowanie programów i projektów utworzenia nowych punktów przejść granicznych, nieefektywność „,zielonej granicy” na skutek sztucznego komplikowania procedury przekraczania, poprzez jeszcze niedawno istniejący wymóg otrzymania wizy szengeńskiej, brak nowoczesnych technologii informacyjno-komunikacyjnych obiegu dokumentów oraz infrastruktury serwisowej na obszarze celnym i terenów przygranicznych po stronie ukraińskiej - wszystko to sprawia, że tworzyły się znaczne kolejki na granicy, co pogarszało wizerunek turystyczny Ukrainy, stwarzało trudności w przekraczaniu granicy dla turystów krajowych i zagranicznych, prowokowało przemyt.

$\mathrm{W}$ celu rozwiązania problemów z otrzymaniem przez obywateli Ukrainy wizy umożliwiającej wjazd na teren Polski na podstawie porozumienia ze stroną polską, ważne jest uproszczenie procedury i mechanizmów otrzymania wiz Schengen, uzgodnienie możliwości wydania większej liczby wiz, zwiększając przez to przepustowość

12 B. Kawałko, Infrastruktura graniczna i ruch graniczny [w:] B. Kawałko, A. Miszczuk (red.), Pogranicze polsko-ukraińskie. Środowisko, społeczeństwo, gospodarka, Zamość-Lublin 2005. 
istniejących konsulatów, a także rozwiązanie na poziomie państwowym problemu etnicznych Ukraińców, przymusowo przesiedlonych w latach 1944-1951 z terytorium Polski, którzy są pozbawieni możliwości swobodnego odwiedzania miejsc bliskich ich pamięci w Polsce. Czynnikiem hamującym jest także niski poziom rozwoju sieci dróg oraz jej infrastruktury. Jedynie $102 \mathrm{~km}(0,57 \%)$ dróg na obszarach obwodów ukraińskich przylegających do granicy ukraińsko-polskiej - zakwalifikowano do pierwszej kategorii ${ }^{13}$.

Ponieważ przez obszary przygraniczne Ukrainy przebiegają międzynarodowe korytarze transportowe i kraj graniczy z krajami członkowskimi UE, niezgodność jakości dróg $\mathrm{z}$ wymaganiami standardów europejskich istotnie zmniejsza możliwości wykorzystania potencjału tranzytowego. Jednak nie można też nie zauważyć, że przejazdy tranzytowych wielotonowych ciężarówek drogami położonymi na obszarach przygranicznych oraz brak dróg objazdowych prowadzą do pogorszenia ich stanu i spadku bezpieczeństwa. Na obecnym etapie proces budowy nowych dróg na Ukrainie otrzymał istotny bodziec ze względu na organizację Euro 2012 na Ukrainie i w Polsce. Ukraińsko-polska współpraca przygraniczna określana jest przez coroczne dwustronne porozumienia. Pod hasłem związku transgranicznego w listopadzie 2003 roku zawarto porozumienie o współpracy gospodarczej i kulturalnej pomiędzy rejonem łuckim a powiatem Kraśnik, w październiku nabrało mocy prawnej porozumienie $\mathrm{z}$ brzeskim obwodowym komitetem wykonawczym o warunkach eksploatacji biłozerskiego systemu wodociągowego kanału Dniepr-Bug. Obwód wołyński i województwo lubelskie podpisały wtedy deklarację o wzajemnej współpracy w ramach organizacji i przeprowadzenia Euro 2012.

Niestety, w większości porozumienia mają charakter deklaratywny. Oprócz tego wszystkie istniejące porozumienia międzyregionalne, które były podpisane pomiędzy jednostkami terytorialno-administracyjnymi do roku 2003, wymagają inwentaryzacji i odnowienia, ze względu na to, że w regionach przygranicznych przeprowadzono reformy polityczne i administracyjne. Sytuacja ta komplikuje realizację współpracy transgranicznej przez nieskoordynowaną działalność organów władzy i samorządu w regionach przygranicznych, której jedną z przyczyn jest niezgodność kompetencji organów władzy i samorządu po obu stronach granicy.

Wśród innych czynników, które obecnie hamują pełne wykorzystanie możliwości współpracy transgranicznej na Ukrainie, można wymienić też: brak całościowej koncepcji polityki państwowej rozwoju regionalnego kraju i podstawy instytucjonalnej rozwoju regionalnego na poziomie narodowym i na poziomach regionalnych; niski procent uczestnictwa w realizacji współpracy transgranicznej instytucji sektorów prywatnego, społecznego i biznesowego, które prowadzą swoją działalność w regionach przygranicznych Ukrainy; przyjmowanie na poziomie centralnych, regionalnych i lokalnych organów władzy wykonawczej Ukrainy współpracy transgranicznej jako dziedziny współpracy zagranicznej oraz niedocenianie jej roli w rozwoju terytorialnym

${ }^{13}$ L. Mazurkiewicz, Region transgraniczny - nowe pojęcie teorii regionu geograficznego [w:] P. Eberhardt, T. Komornicki (red.), Problematyka wschodniego obszaru pogranicza, Biuletyn: Podstawy Rozwoju Zachodnich i Wschodnich Obszarów Przygranicznych Polski, nr 2, Warszawa 1993. 
(przestrzennym) oraz humanitarnym. Zauważalnym czynnikiem hamującym są różnice, które istnieją w mechanizmach udzielania pomocy ze strony UE krajom Europy Środkowej i Wschodniej oraz WNP. W poszczególnych przypadkach różnice te prowadzily nawet do utraty przez jednego z potencjalnych partnerów w regionie przygranicznym krajów Europy Środkowej i Wschodniej lub WNP zainteresowania dalszym uczestnictwem we wspólnym projekcie w ramach współpracy transgranicznej. Oprócz tego Ukraina jako kraj WNP w porównaniu z Polską ma ograniczony dostęp do możliwości, jakie oferuje UE w ramach swoich innych programów lub inicjatyw.

Komisja Europejska przeanalizowała problemy związane z koniecznością współpracy, które przewidują wprowadzenie różnych instrumentów realizacji i proponują nowe warunki na okres 2007-2013. Zamiast TACIC stworzono nowe źródło finansowania o nazwie Europejski Instrument Sąsiedztwa i Partnerstwa (European Neighborhood and Partnership Instrument ( ENPI). Od 2007 roku nowy instrument ENPI zastąpił programy: NFCIS, MEDA, Neighborhood Programms. Ogólny zasięg finansowania nowego instrumentu wynosi $12 \mathrm{mld}^{\text {euro }}{ }^{14}$.

Oprócz tego Europejska Komisja na podstawie Siódmego Programu Ramowego tworzy nowy impuls do utworzenia europejskiej przestrzeni badawczej, która ma na celu rozwój współpracy i stymulowania strumienia inwestycji w regionach, które są bardzo ważne dla podniesienia konkurencyjności i przezwyciężenia technologicznego opóźnienia krajów członkowskich UE oraz ich partnerów strategicznych. Bezsprzecznie, nowy instrument ENPI, program ramowy i Program sąsiedztwa - to unikatowe możliwości dla obwodów przygranicznych Ukrainy. Programy dają możliwość pozyskania dodatkowych środków w formie bezzwrotnej pomocy technicznej w wysokości 5-7 mln euro rocznie w warunkach efektywnej pracy w sferze planowania projektowego oraz zarządzania i operacyjnego systemu współfinansowania ${ }^{15}$. Ale obecnie istnieje pragmatyczna prognoza, że regiony przygraniczne Ukrainy nie będą gotowe na przyswojenie danego zakresu finansowania ze względu na brak infrastruktury instytucjonalnej oraz wykwalifikowanych specjalistów w zakresie projektowego planowania oraz zarządzania, a także ze względu na brak opracowanego schematu wspótfinansowania przez rząd Ukrainy.

Szczególnie ważny wydaje się rozwój współpracy transgranicznej pomiędzy Ukrainą a Polską w sferze turystyki i rekreacji, ponieważ pomimo obecności znacznych zasobów naturalnych, turystyczno-rekreacyjnych oraz kulturalno-historycznych, istnieją tu niewykorzystane rezerwy rozwoju naszego kraju. Aktywizacja ukraińsko-polskiej współpracy transgranicznej w dziedzinie turystyki jest istotnym czynnikiem ludzkim rozwoju przygranicznych obszarów ukraińskich i polskich, co pozytywnie wpływa na sferę stosunków międzyludzkich. Na Ukrainie rozwój turystyki oraz współpracy transgranicznej określają ustawy Ukrainy „O turystyce”

14 О. Мельник, Стратегія прикордонного співробітництва: пленарна сесія Консультат. комітету Президентів Украӥни та Польщฺі / О. Мельник // Уряд. кур“єр. 2007, s. 10.

15 Стратегія транскордонного співробітництва ,, Карпати 2004-2011” (Україна, Польща, Угорщина, Румунія). Проект TACIS, Агентство регіонального розвитку та транскордонного співробітництва „Закарпаття”, Ужгород 2005, s. 47. 
№ 1282-IV z dnia 18.11.2003 roku oraz „O współpracy transgranicznej” № 1861-IV $\mathrm{z}$ dnia 24.06.2004 roku, które zawierają aparat pojęciowy tych sfer. Jednakże przepisy tych aktów normatywno-prawnych nie zawierają mechanizmów i instrumentów realizacji efektywnej polityki państwowej w sferze współpracy transgranicznej w turystyce ${ }^{16}$.

Pośród czynników, które w pewnym stopniu przeszkadzają aktywizacji ukraińsko-polskiej współpracy transgranicznej w sferze turystyki, w pierwszej kolejności należy wymienić problem z uzyskaniem wizy Schengen od 1 stycznia 2008 roku do wjazdu na terytorium Polski dla obywateli Ukrainy, co doprowadziło do zmniejszenia ruchu turystycznego i biznesowego oraz trudności w realizacji wspólnych projektów transgranicznych itd.

W marcu 2008 roku rządy Ukrainy i Polski podpisały porozumienie o małym ruchu granicznym, które nieco zliberalizowało proces uzyskania polskich wiz przez mieszkańców pogranicza ukraińskiego. Zgodnie z porozumieniem, obywatele Ukrainy, którzy mieszkają w 50- kilometrowej strefie, mogli zamiast wiz uzyskać specjalne pozwolenia w formie plastikowych kart. Przy tym przewidywano wiele kategorii osób, które otrzymali pozwolenia bezpłatnie, wśród nich m.in. dzieci i niepełnosprawni. Dla osób, które w ciągu dwóch lat zrealizowali to przemieszczenie bez wykroczeń, przewidywano wydawanie pozwoleń na dłuższy okres - do pięciu lat. Aby porozumienie o małym ruchu granicznym było efektywne, oba państwa powinny wspólnie rozpocząć prace nad utworzeniem nowych przejść granicznych. Polska również zaproponowała Ukrainie w 2008 roku zawarcie jeszcze jednego porozumienia o wprowadzeniu wiz dwustronnych, przeznaczonych dla osób, które mają prawo do nauki i pracy w Polsce, ale wizy te nie są ważne w krajach strefy Schengen. Pragnieniem Ukrainy jest niedopuszczenie do tego, aby ukraińskie granice z sąsiednimi krajami UE stały się barierą dla handlu, turystyki i elementarnej komunikacji między bliskimi sobie ludźmi i krewnymi. W celu swobodnego przepływu ludzi i transportu konieczne jest stworzenie dyrektyw rozbudowy międzynarodowych przejść granicznych lub przeniesienie zadania rozbudowy przejść granicznych na obwodowe organy władzy (stworzenie odpowiednich komitetów) oraz regionalne oddziały celne, poprzez wyodrębnienie części środków z nadwyżki wykonania planu wpływania środków pieniężnych do budżetu państwa. Należy uwzględnić także gotowość strony polskiej do sfinansowania rozbudowy wspólnych przejść granicznych.

Nieodpowiedni poziom wsparcia informacyjno-promocyjnego rozwoju sfery turystycznej na Ukrainie także hamuje ukraińsko-polską turystyczną współpracę transgraniczną. Polska Organizacja Turystyczna, instytucja państwowa, ma swoje przedstawicielstwa we wszystkich regionach Polski, prowadzi efektywną działalność reklamowo-promocyjną ogólnie w kraju poprzez regionalne i zagraniczne przedstawicielstwa. Na Ukrainie z budżetu państwowego nie wydziela się odpowiedniej wielkości środków do promocji turystycznego potencjału kraju, na przykład w budżecie

16 Закон Украйни Про внесення змін до Закону Украӥни “Про туризм”: за станом на 18 лист. 2003 р./ Верховна Рада України. - Офіц. Вид. - К.: Відомості Верховної Ради (ВВР) 2004, № 13, s. 180. 
państwowym Ukrainy w 2007 roku przewidziano 23,3 mln hrywien (3,8 mln euro), co jest niewystarczające do aktywizacji rozwoju sfery turystycznej ${ }^{17}$.

Skutkiem tego jest fakt, że Ukraina nie uzyskuje odpowiednich dochodów z turystyki, pogarsza się turystyczny wizerunek i atrakcyjność Ukrainy jako kraju turystycznego przez niski poziom bezpieczeństwa turystyki, trudności w przekraczaniu granicy, pogorszenie jakości życia mieszkańców obszarów przygranicznych, których dochód w znacznym stopniu uzyskiwany jest $\mathrm{z}$ handlu granicznego towarami i usługami, a także utrzymanie agro- i ekoturystyki oraz zielonych sadyb.

W celu zapewnienia rozwoju ukraińsko-polskiej współpracy transgranicznej w dziedzinie turystyki na poziomie ogólnopaństwowym należałoby zainicjować opracowanie państwowego programu tworzenia turystycznego wizerunku Ukrainy na międzynarodowym rynku turystycznym, uzgodnić przedsięwzięcia Państwowego programu rozwoju współpracy transgranicznej w latach 2007-2010 z zadaniami Państwowego programu rozwoju turystyki na lata 2002-2010 w celu ich współfinansowania z Programu Dobrego Sąsiedztwa Polski-Białorusi-Ukrainy oraz w części odpowiedzialnych wykonawców. Konieczne jest także utworzenie sieci transgranicznych centrów informacji turystycznej oraz regionalnych struktur informacyjno-promocyjnych z uwzględnieniem modelu partnerstwa państwowo-prywatnego i środków z programów międzynarodowej pomocy technicznej, co wpłynęłoby pozytywnie na rozwój współpracy transgranicznej Ukrainy i Polski w sferze turystyki.

W celu zagwarantowania pewnej kwoty z wpływów podatkowych podmiotów działalności gospodarczej w sferze turystyki, rekreacji i obiektów turystycznych z lokalnych oraz obwodowych budżetów w regionach transgranicznych na rozwój infrastruktury turystycznej, sieci drogowej oraz stref obsługi serwisowej wydaje się celowe wprowadzenie zmian do ustawy Ukrainy „O turystyce”.

Po analizie ukraińsko-polskiej współpracy transgranicznej, można więc wysnuć wniosek o jej dynamicznie postępującym rozwoju, wysokiej intensywności dialogu dwustronnego na poziomie lokalnym i regionalnym, co prowadzi do zwiększenia kontaktów międzyludzkich oraz ruchu transgranicznego. W pierwszej kolejności jest to thumaczone wspólnotą interesów krajów sąsiadujących w wielu sferach, ich głębokimi związkami historycznymi i kulturowymi. Dlatego też występowanie wielu problemów, głównie na płaszczyźnie prawnej, poniekąd jest czynnikiem, który negatywnie wpływa na ukraińsko-polską współpracę transgraniczną, co z kolei rzutuje na stosunki międzypaństwowe. Skierowanie wysiłków Ukrainy i Polski na rozwój współpracy regionalnej ma w perspektywie nadać stosunkom transgranicznym cech siły pociągowej, która wprowadzi dwustronne relacje w jakościowo nowy wymiar.

Opierając się na doświadczeniu krajów europejskich (a przede wszystkim Polski), które przeszły drogę od obozu socjalistycznego do członkostwa w UE, można stwierdzić, że istniejących problemów w sferze transgranicznej nie da się rozwiązać półśrodkami. Cel polityki państwowej w sferze współpracy transgranicznej może zostać osiągnięty tylko poprzez wprowadzenie jednolitej i efektywnej polityki rozwoju

17 Закон Украйни Про транскордонне співробітництво: за станом на 24 черв. 2004 p. / Верховна Рада України. - Офіц. вид. Відомості Верховної Ради (ВВР) 2004, № 45, s. 499. 
regionalnego. Ma ona przewidywać stworzenie instrumentów prawnych, instytucjonalnych i finansowych, co w połączeniu z reformą administracyjną zapewniałoby wzmocnienie roli samorządu lokalnego i decentralizację zarządzania państwowego, a to z kolei miałoby bezpośredni wpływ na ukraińsko-polskie więzi.

Podsumowując, należy stwierdzić, że współpraca transgraniczna Ukrainy i Polski sprzyja temu, aby granice państwowe stawały się bardziej przeźroczyste dla stosunków między obywatelami naszych krajów, a także ukraińskimi i polskimi organizacjami społecznymi, aby kontakty dobrosąsiedzkie stale się pogłębiały nie tylko między ludnością, lecz także organami władzy, co sprzyjałoby rozwojowi sieci transportowej, współpracy naukowej i kulturalnej oraz ochronie środowiska naturalnego. Konieczne jest także współdziałania w dziedzinie zapobiegania „transgranicznemu” łamaniu prawa albo działaniom, które zagrażają interesom naszych państw i ich obywateli.

\section{Bibliografia}

Andreasik J., Kawałko B., Kawecka-Wyrzykowska E., Perspektywy przygranicznej wspótpracy polsko-ukraińskiej w świetle członkostwa Polski w Unii Europejskiej, Zamość 2003.

Brodecki Z., Regiony, Warszawa 2005.

Brodecki Z., Mikołajczyk A., Skóra A., Sowiński T., Wiewiórowski W., Zeidler K., Regiony w wybranych państwach członkowskich Unii Europejskiej, Warszawa 2005.

Чорногор В., Центр украӥнсько-польських ініціатив» допомагатиме розвитку прикордонного співробітництва, „В Чорного // Новини Закарпаття” 2007, 27 січ., s. 4.

Europejska Karta Regionów Granicznych i Transgranicznych (do 1995 r. - Europejska Karta Regionów Przygranicznych), http://docplayer.pl/7365320-Europejska-karta-regionow-granicznych-i-transgranicznych-nowelizacja.html [odczyt: 23.06.2016].

Державна Програма розвитку транскордонного співробітництва на 2007-2010 р.p.: за станом на 27 груд. 2006 р. / Постанова Кабінету Міністрів України / Урядовий портал //, http://www.kmu.gov.ua/control/uk/cardnpd?docid=60690971 [odczyt: 04.09.2016].

Kawałko B., Infrastruktura graniczna i ruch graniczny [w:] B. Kawałko, A. Miszczuk (red.), Pogranicze polsko-ukraińskie. Środowisko, społeczeństwo, gospodarka, Zamość-Lublin 2005.

Toczyski W., Sartorius W., Zaucha J., Międzynarodowa wspótpraca regionów. Wybór ekspertyz, Warszawa 1997.

Leseczko M., Globalizacja a rozwój Ukrainy [w:] M. Bałtowski, H. Ponikowski (red.), Problemy rozwoju i zarzadzania w gospodarce globalnej, Lublin 2005.

Mazurkiewicz L., Region transgraniczny - nowe pojęcie teorii regionu geograficznego [w:] P. Eberhardt, T. Komornicki (red.), Problematyka wschodniego obszaru pogranicza, Biuletyn: Podstawy Rozwoju Zachodnich i Wschodnich Obszarów Przygranicznych Polski, nr 2, Warszawa 1993.

Мельник О., Стратегія прикордонного співробітництва: пленарна сесія Консультат. комітету Президентів Украӥни та Польщі / О. Мельник // Уряд. кур“єр. 2007.

Мельник О., Транскордонна співпрачя: співпраия між прикордонними областями України і Польщі / О. Мельник // Уряд. кур’єр. 2006, № 66-67.

Максименко С., Регіональна політика в країнах Європи: Уроки для України, Київ 2000, s. 171.

Rąkowski G., Instytut Ochrony Środowiska: Transgraniczne obszary chronione na wschodnim pograniczu Polski. Zarys koncepcji, Warszawa 2000. 
Стратегія транскордонного співробітництва „Карпати 2004-2011” (Україна, Польща, Угорщина, Румунія). Проект TACIS, Агентство регіонального розвитку та транскордонного співробітництва „Закарпаття”, Ужгород 2005.

Surmacz B., Wspótczesne stosunki polsko-ukraińskie. Politologiczna analiza traktatu o dobrym sasiedztwie, Lublin 2002, s. 191-206.

Закон України Про внесення змін до Закону України „Про туризм”: за станом на 18 лист. 2003 p./ Верховна Рада України. - Офіц. Вид. -К.: Відомості Верховної Ради (ВВР) 2004, № 13.

Закон України Про транскордонне співробітництво: за станом на 24 черв. 2004 р. / Верховна Рада України. - Офіц. вид. - Відомості Верховної Ради (ВВР), 2004, № 45. - 499 с.

Україна і Польща проведуть „дні добросусідства”, http://oglyadach.com/news_print/2006/ 8/26/108966.htm [odczyt: 26.08.2006].

Zioło Z., Czynniki i bariery rozwoju obszarów transgranicznych [w:] K. Miros, A. Stasiak (red.), Polska i jej współdziałanie transgraniczne z sąsiadami, Biuletyn: Podstawy Rozwoju Zachodnich i Wschodnich Obszarów Przygranicznych Polski, nr 10-11, Warszawa 1995. 